\title{
Electronic Cigarettes, Vaping, and Lung Disease: A Short Primer
}

Max Deschner ${ }^{1}$, Marcel Tunks², Cory Yamashita ${ }^{3}$

\author{
${ }^{1}$ Department of Medicine, Western University, London, ON, Canada \\ ${ }^{2}$ Department of Medicine, Division of Respirology, McMaster University \\ ${ }^{3}$ Department of Medicine, Division of Respirology, Western University \\ Received: 15 November 2019; Accepted: 25 May 2020; Published: 18 November 2020 \\ DOI: http://dx.doi.org/10.22374/cjgim.v15i4.408
}

\begin{abstract}
In recent years there has been a proliferation in the practice of vaping to consume nicotineand cannabis-based products. While evidence on the benefits and risks of electronic cigarettes (e-cigarettes) is evolving, this brief primer highlights important new information about vaping for clinicians, researchers and the public. In 2018, the Canadian government passed legislation to regulate tobacco and vaping products. We discuss evidence comparing e-cigarettes versus nicotine replacement therapy for smoking cessation and highlight limitations of this body of research. While e-cigarettes are felt to contain fewer toxins than cigarettes, the long-term effects of vaping remain unknown. Emerging data demonstrates associations between vaping and acute and chronic lung disease. We discuss the emergence of an outbreak of severe lung injury associated with e-cigarette use in the United States and similar cases in Canada. Finally, we review evidence demonstrating the growing prevalence of vaping and smoking amongst Canadian youth.
\end{abstract}

\section{RESUME}

Ces dernières années, on a assisté à une prolifération de la pratique de la vaporisation pour consommer des produits à base de nicotine et de cannabis. Alors que les preuves sur les avantages et les risques des cigarettes électroniques (e-cigarettes) évoluent, ce bref aperçu met en lumière de nouvelles informations importantes sur le vaping pour les cliniciens, les chercheurs et le public. En 2018, le gouvernement canadien a adopté une loi pour réglementer les produits du tabac et les produits à base de vapeur. Nous examinons les données comparant les e-cigarettes et les thérapies de remplacement de la nicotine pour le sevrage tabagique et soulignons les limites de ce corpus de recherche. Bien que l'on estime que les e-cigarettes contiennent moins de toxines que les cigarettes, les effets à long terme des vapeurs restent inconnus. Les données émergentes démontrent des associations entre l'inhalation de vapeurs et les maladies pulmonaires aiguës et chroniques. Nous discutons de lémergence d'une épidémie de lésions pulmonaires graves associées à l'utilisation des e-cigarettes aux États-Unis et de cas similaires au Canada. Enfin, nous passons en revue les preuves démontrant la prévalence croissante des vapeurs et du tabagisme chez les jeunes Canadiens. 
There are growing concerns regarding the proliferation of vaping products in Canada. With increased use of, mainly, nicotine and cannabis-based products, the legal, social, and medical landscapes of electronic cigarettes (e-cigarettes) continue to evolve. While governments and the public grapple with issues around the regulation and safe use of e-cigarettes, physicians also face questions about the role of e-cigarettes in smoking cessation, associations between e-cigarettes and lung disease, and the rising popularity of vaping products among youth. In view of emerging evidence on the potential public health risks and benefits of e-cigarette use, this article offers a brief primer for physicians on important new information about e-cigarettes and vaping.

Vaping involves inhaling and exhaling aerosols produced when an electronic cigarette or similar device heats a substance such as nicotine, tetrahydrocannabinol (THC), or cannabidiol (CBD). Combusted aerosols are generally in liquid form; however, some vaping products may enable combustion of solid or dried substances like cannabis. E-cigarettes have gone through several generational designs since their introduction in the early 2000s but traditionally have included a battery, a mouthpiece, a heating device, and a chamber containing liquid solution. Depending on the maker and generation, e-cigarettes may be called cigalikes, vape pens, mods, e-hookahs, tank systems, pod vapes, or electronic nicotine delivery systems (ENDS). Older generation devices like cigalikes are disposable and cannot be recharged or refilled. Newer generation devices tend to be rechargeable, feature refillable cartridges, and may deliver relatively higher concentrations of nicotine compared with older devices. Vaping devices may include additives such as chemical flavorings, propylene glycol, glycerol, benzoic acid, or vitamin $\mathrm{E}$ acetate, a synthetic form of vitamin $\mathrm{E} .{ }^{1}$

E-cigarettes are approved for sale in Canada and regulated under federal law. The Tobacco and Vaping Products Act (TVPA) - passed in May 2018-regulates manufacturing, sales, labeling, and advertising of tobacco and vaping products in Canada. ${ }^{2}$ This law authorizes the federal government to ban certain ingredients in vaping devices and prohibits minors from using tobacco and vaping products. The Cannabis Act governs the production, distribution, sale, and possession of cannabis across Canada. ${ }^{3}$ Other federal regulations governing vaping include the Canada Consumer Product Safety Act, the Food and Drugs Act, and the Non-smokers' Health Act. ${ }^{4}$

In recent years, nicotine-based e-cigarettes have grown in popularity, in part, because they may be perceived by the public, some physicians, and healthcare organizations as a less harmful alternative to traditional tobacco cigarettes. This has led to their use as a smoking cessation tool in some jurisdictions. While e-cigarettes are not approved by Health Canada for smoking cessation, Public Health England recommends tobacco smokers try regulated nicotine vaping products in addition to smoking cessation medications and behavioral support interventions. ${ }^{5}$ European Union regulations limit the nicotine concentration in vaping liquids to a maximum of $20 \mathrm{mg} / \mathrm{mL}$ while Canada limits concentrations to $66 \mathrm{mg} / \mathrm{mL} .{ }^{6,7}$ Unlike other approved tools for smoking cessation, e-cigarettes did not undergo robust pre-clinical safety or efficacy studies before being introduced for sale. ${ }^{8} \mathrm{~A}$ recent randomized, controlled trial comparing e-cigarettes to nicotine replacement therapy (NRT) over 3 months found that at 1 year, $18 \%$ of e-cigarette users versus $9.9 \%$ of NRT users abstained from tobacco $(\mathrm{P}<0.001) .{ }^{9}$ However, it is worthwhile noting that $80 \%$ of e-cigarette subjects compared with $9 \%$ of NRT subjects were still using their assigned method at the end of study follow-up. ${ }^{9}$ It remains unclear whether e-cigarettes extend nicotine dependency or prompt relapse to tobacco cigarette smoking among former smokers. ${ }^{10}$ More studies are needed comparing e-cigarettes with other Health Canada-approved smoking cessation tools such as varenicline and bupropion.

Emerging data have highlighted the development of acute, sub-acute, and chronic lung injury among individuals who vape. Vaping has been associated with chronic bronchitic symptoms and development of asthma and chronic obstructive pulmonary disease. ${ }^{11-13}$ Studies in humans have suggested associations between vaping and ciliary dysfunction, immune suppression, and delayed recovery from pulmonary infection. ${ }^{14,15}$ Although studies suggest some biological plausibility that e-cigarettes may be linked to lung injury, the population health effects of vaping may not be evident for years-just as the long-term health effects of tobacco smoking (including causal links to lung cancer) took decades to become apparent. No long-term toxicology or safety studies on e-cigarettes and vaping have been completed in humans. ${ }^{8}$ As such, statements about the relative safety of e-cigarettes over tobacco cigarettes cannot be made conclusively.

Various forms of acute and sub-acute lung injury have been linked to vaping. In August 2019, the US Centers for Disease Control (CDC) reported an outbreak of severe lung injury associated with e-cigarette use across the United States (US). The number of cases peaked in September 2019 and declined through early 2020. ${ }^{1,16}$ Various patterns of lung injury have been described including acute eosinophilic pneumonia, organizing pneumonia, diffuse alveolar hemorrhage, diffuse alveolar damage, and acute respiratory distress syndrome. ${ }^{17}$ The CDC termed this group of conditions "e-cigarette or vaping product use-associated lung injury" or EVALI. As of February 18, 2020, a total of 2807 cases of EVALI were reported in the US, including 68 deaths. ${ }^{1}$ In Canada, as of April 7, 2020, a total of 19 cases of vaping-associated lung illness were reported to the Public Health Agency of Canada. ${ }^{18}$ It is noteworthy that THC use either alone 
or in combination with nicotine was identified in nearly $80 \%$ of early cases in the US. ${ }^{16}$ Only seven of 19 cases in Canada were associated with THC-containing products. ${ }^{18}$ Although no deaths had been reported in Canada, severe cases had emerged including one patient with vaping-associated acute bronchiolitis who required intubation and extracorporeal membrane oxygenation, and developed chronic airway obstruction after resolution of the critical illness. ${ }^{18,19}$ In November 2019, the CDC reported that laboratory testing of bronchoalveolar lavage samples from 29 patients with evidence of EVALI from across the US found vitamin $\mathrm{E}$ acetate in all samples. ${ }^{1}$ The results showed $82 \%$ of samples contained THC and $62 \%$ contained nicotine. ${ }^{1}$ Many products linked to cases of EVALI in the US were obtained from the black market, leading to concern that vitamin E acetate was used to thicken or dilute illicit THC-based vaping liquids. ${ }^{20,21}$ While vitamin E acetate has been highly associated with EVALI, it still appears that no single product accounts for all case findings in Canada and the US. In view of the outbreak, the CDC has recommended that individuals completely abstain from THCcontaining e-cigarettes. ${ }^{1}$ Health Canada has issued a warning about potential risks of pulmonary illness associated with vaping and recommended avoiding vaping products obtained from illegal or unregulated sources. ${ }^{18}$

While the long-term health effects of inhaling aerosolized compounds remain unknown, evidence is clear that vaping among youth is on the rise. An analysis of cross-sectional surveys showed that the prevalence of smoking tobacco and vaping among Canadian youth aged 16-19 years increased between 2017 and $2018(\mathrm{P}<0.001) .{ }^{11}$ It has been speculated that targeted advertising of vaping products to youth may play a key role in this observation. For example, one study found that young people who recalled seeing e-cigarette marketing in retail stores were more likely to initiate vaping up to 2.5 years later (adjusted odds ratio [aOR] 1.99, $\mathrm{P}<0.05)(\mathrm{aOR} 1.30, \mathrm{P}<$ $0.05) .^{22}$ Furthermore, e-cigarette use is linked to increased use of tobacco cigarettes among youth. ${ }^{23}$ Although a direct causal pathway has not been proven, a prospective cohort study found an association between 30-day use of e-cigarettes and smoking a whole cigarette (aOR 2.12) and daily smoking (aOR 1.79). ${ }^{23}$

In summary, e-cigarette use has increased in recent years, particularly among young people and smokers who are attempting to quit. While evidence evolves about the risks and benefits of vaping, studies suggest e-cigarettes are associated with the development of acute, sub-acute, and chronic lung disease and increased tobacco use among youth. More robust research is needed to determine the short-term and long-term health consequences of vaping in view of the growing array of substances and products available in regulated and illicit markets. This will give physicians the information to better counsel patients and contribute to future public health discussions and policies.

\section{References}

1. Centers for Disease Control and Prevention. Outbreak of lung injury associated with the use of e-cigarette, or vaping, products [Internet]. 2020. Available from: https://www.cdc.gov/tobacco/basic_information/e-cigarettes/ severe-lung-disease.html

2. Government of Canada. Tobacco and Vaping Products Act S.C. 1997, c. 13, s. 1; 2018, c. 9, s. 2 [Internet]. 2019. Available from: https://laws-lois.justice. gc.ca/eng/acts/t-11.5/page-1.html

3. Government of Canada. Cannabis act S.C. 2018, c. 16 [Internet]. 2019. Available from: https://laws-lois.justice.gc.ca/eng/acts/c-24.5/

4. Health Canada. Vaping product regulations [Internet]. 2020. Available from: https://www.canada.ca/en/health-canada/services/smoking-tobacco/vaping/ product-safety-regulation.html

5. McNeill A, Brose L, Caulder R, Bauld L, Robson D. Vaping in England: An evidence update including mental health and pregnancy, March 2020: A report commissioned by Public Health England [Internet]. Available from: https://www.gov.uk/government/ publications/vaping-in-england-evidence-update-march-2020/ vaping-in-england-2020-evidence-update-summary-authors-and-citation

6. European Union. Tobacco products directive (Directive 2014/40/EU) [Internet]. 2014. Available from: https://ec.europa.eu/health/sites/health/ files/tobacco/docs/dir_201440_en.pdf

7. Government of Canada. Vaping products labelling and packaging regulations, SOR/2019-353 [Internet]. 2019. Available from: https://laws-lois.justice.gc.ca/ eng/regulations/SOR-2019-353/FullText.html

8. Gotts JE, Jordt SE, McConnell R, Tarran R. What are the respiratory effects of e-cigarettes? BMJ. 2019;366:15275. http://dx.doi.org/10.1136/bmj.15275

9. Hajek P, Phillips-Waller A, Przulj D, Pesola F, Smith KM, Bisal N, et al. A randomized trial of e-cigarettes versus nicotine-replacement therapy. N Engl J Med. 2019;380(7):629-37. http://dx.doi.org/10.1056/NEJMoa1808779

10. Caponnetto P, DiPiazza J, Cappello GC, Demma S, Maglia M, Polosa R, et al. Multimodal smoking cessation in a real-life setting: Combining motivational interviewing with official therapy and reduced risk products. Tob Use Insights. 2019;12:1179173X19878435. http://dx.doi. org/10.1177/1179173X19878435

11. Hammond D, Reid JL, Rynard VL, Fong G, Michael CK, McNeill A, et al. Prevalence of vaping and smoking among adolescents in Canada, England, and the United States: Repeat national cross sectional surveys. BMJ. 2019;365:12219. http://dx.doi.org/10.1136/bmj.12219

12. Wills TA, Pagano I, Williams RJ, Tam EK. E-cigarette use and respiratory disorder in an adult sample. Drug Alcohol Depend. 2019;194:363-70. http:// dx.doi.org/10.1016/j.drugalcdep.2018.10.004

13. McConnell R, Barrington-Trimis JL, Wang K, Urman R, Hong H, Unger $\mathrm{J}$, et al. Electronic cigarette use and respiratory symptoms in adolescents. Am J Respir Crit Care Med. 2017;195(8):1043-9. http://dx.doi.org/10.1164/ rccm.201604-0804OC

14. Carson JL, Zhou L, Brighton L, Mills KH, Zhou H, Jaspers I, et al. Temporal structure/function variation in cultured differentiated human nasal epithelium associated with acute single exposure to tobacco smoke or E-cigarette vapor. Inhal Toxicol. 2017;29(3):137-44. http://dx.doi.org/10.1080 /08958378.2017.1318985

15. Martin EM, Clapp PW, Rebuli ME, Pawlak EA, Glista-Baker E, Benowitz NL, et al. E-cigarette use results in suppression of immune and inflammatoryresponse genes in nasal epithelial cells similar to cigarette smoke. Am J Physiol Lung Cell Mol Physiol. 2016;311(1):L135-44. http://dx.doi. org/10.1152/ajplung.00170.2016 
16. Perrine CG, Pickens CM, Boehmer TK, King BA, Jones CM, DeSisto CL, et al. Characteristics of a multistate outbreak of lung injury associated with e-cigarette use, or vaping-United States, 2019. MMWR Morb Mortal Wkly Rep. 2019;68(39):860-4. http://dx.doi.org/10.15585/mmwr.mm6839e1

17. Christiani DC. Vaping-induced lung injury. N Engl J Med. 2020;382:960-2. http://dx.doi.org/10.1056/NEJMe1912032

18. Government of Canada. Vaping-associated lung illness [Internet]. 2020 Apr 16. Available from: https:/www.canada.ca/en/public-health/services/ diseases/vaping-pulmonary-illness.html\#al

19. Landman ST, Dhaliwal I, Mackenzie CA, Martinu T, Steele A, Bosma KJ, et al. Life-threatening bronchiolitis related to electronic cigarette use in a Canadian youth. CMAJ. 2019;191(48):E1321-31. http://dx.doi.org/10.1503/ cmaj. 191402

20. Layden JE, Ghinai I, Pray I, Kimball A, Layer M, Tenforde M, et al. Pulmonary illness related to e-cigarette use in Illinois and
Wisconsin-Preliminary report. N Engl J Med. 2020;382:903-16. http:// dx.doi.org/10.1056/NEJMoa1911614

21. Kirkham C, Dastin J. Explainer: One possible culprit in vaping lung illnesses_"Dank Vapes". Reuters [Internet]. September 13, 2019. Available from: https:/www.reuters.com/article/us-health-vaping-industry-explainer/ explainer-one-possible-culprit-in-vaping-lung-illnesses-dank-vapesidUSKCN1VY2ET

22. Loukas A, Paddock EM, Li X, Harrell MB, Pasch KE, Perry CL. Electronic nicotine delivery systems marketing and initiation among youth and young adults. Pediatrics. 2019;144(3):e20183601. http://dx.doi.org/10.1542/ peds.2018-3601

23. Hammond D, Reid JL, Cole AG, Leatherdale ST. Electronic cigarette use and smoking initiation among youth: A longitudinal cohort study. CMAJ. 2017;189(43):E1328-36. http://dx.doi.org/10.1503/cmaj.161002 